\title{
From Politics to the Family: How Sex-Role Attitudes Keep on Diverging in Reunified Germany
}

\author{
Stefan Bauernschuster \\ Helmut Rainer
}

CESIFO WORKING PAPER NO. 2957

CATEGORY 4: LABOUR MARKETS

FEBRUARY 2010
An electronic version of the paper may be downloaded
- from the SSRN website:
- from the RePEc website:
www.SSRN.com
- from the CESifo website:
www.RePEc.org
www.CESifo-group.org/wp




\title{
From Politics to the Family: How Sex-Role Attitudes Keep on Diverging in Reunified Germany
}

\begin{abstract}
What is the role of politics in shaping attitudes about appropriate roles for women in the family and the compatibility of work and motherhood? In this paper we argue that the German separation and later reunification produced a natural experiment to address this question. During the divided years, East German institutions encouraged high levels of fulltime employment for women, including mothers. The West German system by contrast deterred women in general, and mothers in particular, from full-time employment. After reunification, family-related policies largely converged in the two Germanies. Against this background, we empirically investigate gender-role attitudes in reunified Germany. Our results show that East Germans are significantly more likely to hold egalitarian or nontraditional sex-role attitudes than West Germans. Despite a scenario of partial policy convergence, we also find evidence that the gap between East and West German gender role attitudes more than doubled in the years after reunification. We suggest that one explanation for this divergence could be found in the notion of social identity.
\end{abstract}

JEL-Code: J13, J16.

Keywords: political regimes, gender role attitudes.

Stefan Bauernschuster

Ifo Institute for Economic Research at the

University of Munich

Poschingerstrasse 5

81679 Munich

Germany

bauernschuster@ifo.de
Helmut Rainer

Ifo Institute for Economic Research at the University of Munich

Poschingerstrasse 5

81679 Munich

Germany

rainer@ifo.de

February 9, 2010

We are indebted to Hans Hvide for helpful comments. 


\section{Introduction}

Attitudes and beliefs concerning appropriate roles for men and women in the family

and the workplace influence economic outcomes. First, there is evidence of a strong negative correlation between traditional or anti-egalitarian views and female employment (Thornton et al., 1983; Fortin, 2005). Second, differences in beliefs about appropriate sex roles across geographically differentiated groups turn out to have significant explanatory power for the work and fertility behavior of women (Fernandez and Fogli, 2009). Third, gender differences in labor market outcomes are not just the result of discrimination but also partially reflect women's own beliefs about appropriate gender roles (Fortin, 2005). Finally, parental sex-role attitudes appear to play a significant role in shaping the attitudes and behavior of children. For example, whether a man's wife works is positively associated with whether his mother worked (Fernandez et al., 2004), which could be explained with the idea that men with working mothers have more egalitarian views of sex roles.

Despite the mounting evidence that sex-role attitudes matter, research on the factors involved in the formation and the evolution of such attitudes is scarce. In particular, very little is known about whether individual beliefs about gender roles are endogenous to politics. In this paper we follow the empirical approach of Alesina and Fuchs-Schündeln (2007) and argue that the separation and reunification of Germany sets up a natural experiment of sorts concerning the influence of political regimes and social policies on attitudes about appropriate roles for women in the family and the compatibility of work and motherhood. Central to our analysis is the use of West Germans as a control group for East Germans. The argument for using this approach is as follows. Prior to separation, East and West Germany were quite similar, amongst other things, in terms of fertility and female employment rates, suggesting no substantial difference in gender role attitudes. Then new political and economic systems were twice imposed in the East, once when Germany was divided in 1949 and again when it was reunified in 1990. During the divided years, institutions and policies that allow women to combine paid work and parenting differed markedly in the two Germanies. The East German politico-economic system not only granted women the constitutional right to work and to receive equal pay, but also encouraged high levels of female employment through extensive public provision of child care and reduced working hours for mothers (Trappe, 1996). West German institutions and policies, by contrast, deterred women in general and mothers in particular from paid work. Those women who chose employment were incentivized-through tax policy and half-day nurseries - to work part-time (Rosenfeld et al., 2004). After reunification, a scenario of institutional convergence emerged. More precisely, family-related policies 
rapidly changed in the East, while those in the West remained largely unchanged.

Against this background, we examine the impact of changing political regimes and social policies on individual sex-role attitudes. The data we use comes from the German General Social Survey (ALLBUS). Our first set of results shows that individuals in the eastern part of reunified Germany are significantly more likely to hold egalitarian or nontraditional sex-role attitudes than their western counterparts. For example, being from East Germany reduces the likelihood of agreeing with the statement "It is better for all if the husband works and the wife stays at home taking care of the household and the children" by roughly 24 percentage points. We interpret this as evidence that the state socialist system in East Germany had a discernible effect on people's thinking about appropriate gender roles. Having established this, we ask of the data whose beliefs are more important in shaping the East-West gap in sex-role attitudes, men's or women's? We show that the beliefs of both East German men and women play an important role, though perhaps surprisingly, men's views appear to be, if anything, more important in driving the gap in sex-role attitudes between East and West Germany. This could be explained with the fact that a substantially larger portion of men in the East grew up with a working mother than in the West.

Lastly, we investigate whether the institutional transformations that took place after reunification - with substantially more change in the East than in the West - are reflected in a convergence of views about gender roles. A remarkable picture emerges. For none of our outcome variables we find evidence of a convergence process. We show quite to the contrary that there is a widening of the East-West gap in sex-role attitudes over the period after 1990. This result is not only statistically significant and robust across a number of specifications, but also quantitatively substantial. For example, regarding disagreement with the statement "It is more important for a woman to support her husband's career instead of making her own", the gap between East and West Germans more than doubled in the first fifteen years after reunification. One potential explanation for this striking divergence in sex-role attitudes could be found in the notion of social identity (Akerlof and Kranton, 2000, 2005). East Germans as a social group only began to identify themselves as such a few years after reunification. After that, their identity led them to hold gender views in concert with the goals of the past socialist regime. The adaption of increasingly egalitarian gender views after reunification could thus be interpreted as an identity-conserving strategy - one that might reflect individuals' positive evaluation of the high value given to gender equality under socialism. In that sense, the divergence of sex-role attitudes in reunified Germany could be interpreted as a long-term effect of the 
socialist regime in the East. ${ }^{1}$

Our work is by no means the first in the study of preferences and attitudes to exploit the German separation and later reunification. In a seminal paper, Alesina and FuchsSchündeln (2007) looked at the extent to which the communist regime in East Germany affected people's thinking about redistribution from the rich to the poor. They find that East Germans are much more in favor of redistribution than West Germans. They also detect signs of a convergence process. More precisely, they show that it will take roughly two generations for the difference between East and West Germans to disappear. The present paper demonstrates that the exact opposite - namely a divergence process emerged when it comes to individual views of sex roles. In addition to the aforementioned study focusing on preferences for redistribution, there has been work examining social capital in reunified Germany. Rainer and Siedler (2009) show that the communist regime in East Germany had a negative effect on people's social and institutional trust. They also find evidence that the transition to democracy led to a sharp increase in institutional trust amongst East Germans. Finally, Bauernschuster et al. (2009) empirically compare individuals born and raised under socialism in East Germany to their West Germans counterparts, and find that the socialist regime had a causal effect on attitudes which are negatively associated with entrepreneurship.

The remainder of this paper is organized as follows. Section two discusses some background to the German separation and later reunification. Section three of the paper describes the data we use, and Section four presents the results. Section five concludes.

\section{Institutional Background}

\subsection{Before Separation}

After a period of multiple political and territorial changes, the second half of the 19th century saw the emergence of gradual conformity between German regions. This development found its institutional imprint in the foundation of the German Empire in 1871. After World War I, the period of the Weimar Republic further supported this development. The regions that would later become East and West Germany were parts of one federal republic. This political and institutional background of Germany is crucial for our identification strategy.

In order to isolate the causal impact of the socialist regime on sex-role attitudes, a key identifying assumption is that East and West Germans did not differ from each other in

\footnotetext{
${ }^{1}$ The historical data reported in this section is available at http://www.digizeitschriften. $\mathrm{de} / \mathrm{main}=/ \mathrm{dms} / \mathrm{img} /$ ?PPN=PPN514401303_1935.
} 
terms of gender views prior to German separation. Unfortunately, we do not have data on reported sex-role attitudes in East and West Germany before separation. However, we do have historic data on variables that are closely related to sex-role attitudes. These data should give us at least some impression about sex roles in East and West Germany in the first half of the last century. For example, data from the Statistisches Reichsamt (1936, p. 322, p. 334) indicate that female labor market participation did hardly differ between what is today's East Germany and West Germany. In 1935, 31 percent of all employed and unemployed were female in the regions of today's East Germany; in West Germany this figure is only slightly lower (30.14 percent). As far as marriage behavior and fertility is concerned, historical data again support our assumption that East and West Germans did not systematically differ before separation (Statistisches Reichsamt, 1936, p. 36). The same is true for female working hours as compared to male working hours and female wages as compared to male wages (e.g., Statistisches Reichsamt, 1936, p. 342). Schäfgen (1998) presents complementary statistics to show that in 1955, labor force participation rate among females was 52.2 percent in East Germany; the corresponding figure for West Germany comes from 1960 and is 49 percent. Only in the course of the following decades, East and West Germans gradually diverged due to orthogonal politico-economic regimes and family-related policies.

\subsection{During the Divided Years}

During the divided years, the two Germanies encouraged women to combine paid work and the family in very different ways. In East Germany, the principle of "equal pay for equal work" was made part of the first constitution in 1949. During the 1960s, the policy focus in the East was on giving women special opportunities to improve their qualifications. This orientation came about within the context of an accelerated development of the economy's scientific and technical level (Huinink and Solga, 2007). By the 1970s, the regime recognized that women's increasing employment seemed to be associated with lower fertility rates (Engelhardt et al., 2002). In the latter years of the socialist regime, the policy focus therefore changed from qualified employment to the reconciliation of work and maternity. In addition to providing extensive child care, the implemented policies made it possible for women to take paid leaves with a job-return guarantee after childbirth and to reduce working hours while the children were small (Trappe, 1996).

In West Germany, by contrast, combining work and family was difficult for women due to the lack of public child care (Rosenfeld et al., 2004). Family policy centered around extended maternal leave for child care, which allowed mothers to stay at home with 
their children, depending economically on their partners and a means-tested payment. During their time of nonemployment, women's entitlement's were largely derived from their husbands' rights (Engelhardt et al., 2002). Overall, therefore, West German policy encouraged a male breadwinner model in which women worked until they had children and then either stayed at home or returned to part-time work after a long interruption.

Taken together, the discussion so far is suggestive that our comparison of sex-role attitudes between East and West Germans is embedded in a natural experiment. On the one hand, the two Germanies differed remarkably in family-related policies and institutions during the forty years of separation. On the other hand, both parts resembled each other economically, politically and culturally before the exogenously imposed separation in 1949. If individual beliefs about gender roles are endogenous to political regimes, this should be visible in differential sex-role attitudes in the two parts of reunified Germany.

\subsection{After Reunification}

After reunification, family-related policies and institutions largely converged in the two Germanies. One notable exception is the public supply of child care. On on side, the institutional transformations that took place after reunification led to a slight decrease in the provision of public child care in the East. However, publicly provided child care in East Germany nevertheless remained at a higher level than in West Germany (Rosenfeld et al., 2004). Another notable exception is the percentage of public jobs that are in the public sector, which was still higher in the East than in the West. Given this scenario of partial policy convergence, an interesting question to ask is whether a unification of gender role attitudes took place after 1990.

\section{Data}

The ALLBUS survey (Allgemeine Bevölkerungsumfrage der Sozialwissenschaften) is a valuable data source for our research. ALLBUS is the German equivalent to the U.S. General Social Survey (GSS) and currently covers the period from 1980 to 2008. ${ }^{2}$ The dataset is based on biennial, representative surveys of the German population conducted through personal interviews. These surveys cover a wide range of topics pivotal to empirical research in social sciences. A core set of questions is asked in every wave of the

\footnotetext{
${ }^{2}$ The ALLBUS program was financially supported by the German Research Foundation (DFG) from 1980 to 1986 and in 1991. Further surveys were financed on a national and federal state (Laender) level via the GESIS network (Gesellschaft Sozialwissenschaftlicher Infrastruktureinrichtungen).
} 
survey, with various sets of additional questions added in different years. ${ }^{3}$ We use the 1991, 1992, 1996, 2000, 2004, and 2008 waves. In these years, interviewees were asked to report their level of agreement with six statements about the role of women in families, where respondents could choose "Fully agree", "Rather agree", "Rather don't agree", or "Don't agree at all" for each single statement. The first three statements concern attitudes about the compatibility of work and motherhood, while the other three statements capture attitudes about the appropriateness of specialization of male and female roles. In particular, the statements belonging to the first group read:

(I) "A working mother can just as well have a hearty and trustful relationship with her children as a non-working mother"

(II) "It is even good for a child if his or her mother is employed instead of merely focusing on household work"

(III) "Certainly, a baby would suffer if his or her mother is employed".

On the other hand, the statements referring to appropriateness of segregation of male and female roles read:

(IV) "It is more important for a woman to support her husband's career instead of making her own career"

(V) "It is better for all if the husband works and the wife stays at home taking care of the household and the children"

(VI) "A married woman should turn a job down if only a limited number of jobs is available and her husband is able to make a living for the family".

In order to give a first impression of the extent to which East Germans and West Germans differ in their attitudes towards a woman's role in the family, we group the two agreement levels ("Fully agree", "Rather agree") together to represent individuals who agree with the respective statement, and group the two disagreement levels ("Rather don't agree", or "Don't agree at all) together to capture individuals who do not agree. We then create six dummy variables which we order so that a value of one reflects an egalitarian or nontraditional response and a value of zero represents a traditional orientation. Thus, positive coefficients on the explaining variables will reflect more egalitarian or nontraditional views about gender roles.

\footnotetext{
${ }^{3}$ Terwey and Baltzer (2009) provide detailed information on the ALLBUS surveys in general and present all variables available in the cumulated dataset from 1980 until 2008.
} 
The six dummy variables are used as outcome variables of probit regressions where our independent variable of main interest is a dummy for East Germany. Additionally, we control for an individual's gender, age (and its square), and education. Moreover, we include a set of year dummies to capture common time trends. In addition to the probit models, we also ran ordered probit models using all information on the four agreement categories, which did not change our results. In extended specifications, we also included marital status, labor force status, occupation, an individual's monthly income, and, in order to proxy for wealth, introduce a dummy variable which takes the value of unity for individuals owning a flat or a house, and is zero otherwise. Moreover, a set of dummy variables to capture regional size effects (e.g., small village, small town, town, or city) is used. Including all these additional covariates does not alter our main findings. However, they give rise to various endogeneity concerns, which (at least) unnecessarily complicates the interpretation of the coefficients. This is why in the rest of this paper, we focus on our basic specification. Summary statistics for all variables used in the paper are in the Appendix.

\section{Results}

\subsection{Baseline Results}

The results presented in Table 1 show that East Germans hold more egalitarian gender views than do West Germans. The difference between East and West in terms of sex-role attitudes is not only highly significant across all six specifications, but also quantitatively substantial. Conditional on our controls, being from East Germany increases the likelihood of agreeing with the statement "It is even good for a child if his or her mother is employed instead of merely focusing on household work" by more than 30 percentage points [specification (II)]. Moreover, concerning the statement that "It is better for all if the husband works and the wife stays at home taking care of the household and the children", being from East Germany decreases the likelihood of agreeing by 24 percentage points [specification (V)]. Note that these differences between East and West Germans are averaged over 19 post Reunification years. We will later come back to that and analyze the dynamics of these gaps in more detail. The coefficients on our covariates seem sensible. On average, women hold more modern views about working mothers and their relationships to their children as well as about family models. Moreover, having rather traditional attitudes toward working mothers and family models is a u-shaped function of age. Schooling seems to decrease agreement with more traditional attitudes toward 
working mothers and family models. ${ }^{4}$ Indeed, the coefficients steadily increase with the level of schooling for all six outcome variables. Additionally, the increasing coefficients of the year dummies indicate that over the past two decades, individuals adopted more modern views about working mothers and family models.

So far, we have seen that East Germans are less traditional or more egalitarian than West Germans when it comes to views about the compatibility of work and motherhood and the appropriateness of specialization of male and female roles. But it would be interesting to know more details about the structure of these differences. First, we might wonder whether the East Germany dummy is mainly driven by men or women. The results reported in Table 2 sheds light on this issue. Splitting the sample by gender and running separate regressions, we find that both East German men as well as women differ in their attitudes from their West German fellow citizens. However, interestingly, for four out of six outcome variables the coefficient on the East Germany dummy is considerably larger in the male subsample (second panel of Table 2) than in the female subsample (first panel of Table 2). This leaves us with the conclusion that the gaps between East and West Germans are to a substantial degree driven by men.

If the observed differences concerning sex roles are a causal effect of the socialist regime in the former GDR, we should see these effects in virtually every single federal state of today's Eastern Germany. In order to test this prediction, we run regressions where we include dummies for East Berlin and the five East German federal states (Brandenburg, Mecklenburg Western Pomerania, Saxony-Anhalt, Saxony, and Thuringia) rather than one East Germany dummy; just like in our earlier regressions we use West Germans as the baseline category. The results of this exercise are displayed in Table 3. As can be seen, there is evidence that individuals from every single East German federal state hold a more egalitarian and less traditional gender role attitudes than the average West German. The coefficients of the remaining covariates are not affected by this alternative specification. It might be interesting to note that West German TV programs could not be received in parts of Saxony and Mecklenburg Western Pomerania whereas they could be received in the remaining East German federal states. One might therefore argue that individuals from Saxony and Mecklenburg Western Pomerania are even more different from West Germans than East Germans from East Berlin, Brandenburg, Saxony-Anhalt and Thuringia. Our results do not support this hypothesis.

\footnotetext{
${ }^{4}$ In controlling for education, we eliminate any indirect effects that political regimes may have on gender role attitudes through the education channel. Regimes that promote a male breadwinner model are less likely to induce female human capital investments than regimes which encourage female employment.
} 


\subsection{Family Values and Mobility}

Now we switch the focus to those 214 East Germans in our sample who moved to West Germany after the fall of the Berlin Wall and compare them to those individuals who were born in West Germany and still live there. ${ }^{5}$ This subpopulation of movers was socialized in the socialist regime of the former GDR and was then confronted with the economic and institutional situation of West Germany. The results reported in Table 4 indicate that this very selective subgroup of East Germans is also significantly different from the average West German for five out of our six outcome variables. A comparison of the East-West movers to those who still live in East Germany reveals that - although very different from West Germans - the movers are somewhat less egalitarian than the average East German. This can be seen from the coefficients of the East-West mover dummy which are consistently smaller than the East dummies in Table 1. We can interpret this finding in two ways: it might be that, once in West Germany, the former East Germans to a certain degree adopt the gender role attitudes of their West German peers. On the other hand, there might also be self-selection at play in the sense that those who are more traditional in terms of family values choose to move from East Germany to West Germany. Unfortunately, we do not have panel data which would allow us tracking individuals over time and thus testing these hypotheses more rigorously.

To complete the picture, we perform an anti-test and switch to those 431 individuals in our sample who moved from East Germany to West Germany before the Berlin Wall was built. Just as expected, this subgroup does not differ at all from the average West German in terms of attitudes toward working mothers and family values. Unfortunately, the very low number of West Germans who moved to East Germany does not allow an analysis similar to the one for individuals who moved from East Germany to West Germany.

\subsection{Cohort Analysis}

In a next step, we analyze the gap in sex-role attitudes between East and West Germans across cohorts. In particular, we define five groups according to the year of birth: born before 1935, born between 1935 and 1945, born between 1945 and 1955, born between 1955 and 1965, and born after 1965. We split the whole sample and run probit regressions for every cohort subsample, using the dummy for East Germany as our variable of main interest. All estimations include the usual covariates. The interesting pattern arising from this exercise is becomes apparent in Table 5. The difference concerning gender role

\footnotetext{
${ }^{5}$ Since this mobility information is not available for 1996 and 2008, we drop all observations from those years.
} 
attitudes between East and West Germans is largest for the earliest cohort, and this holds true for all six outcome variables dealing with either attitudes about the compatibility of work and motherhood or views about the appropriateness of specialization of male and female roles. Indeed, we observe a strikingly consistent decrease in the coefficients on the East dummies once we move to later cohorts. We might interpret this finding along the lines of Alesina and Fuchs-Schündeln (2007): those East Germans who lived under the socialist regime for a longer time show the biggest differences from West Germans. Given that the gap between East and West Germans is largest for the earlier cohorts and smaller for the young, we might also wonder whether we can observe a certain convergence process in family values between East and West Germans in the years after Reunification.

\subsection{Dynamics}

Since we have got repeated cross-section data on family values for the period from 1991 to 2008, we can explore whether the differences between East and West Germans decreased in the course of the years after Reunification. In order to analyze whether a convergence process emerges, we interact the East German dummy with year dummies for 1996, 2000, 2004, and 2008. Then, we include these interaction terms in addition to the East Germany dummy, the year dummies, and the usual covariates in our probit models. If the coefficients on the interactions show the opposite sign of the East German dummy coefficients, this indicates the presence of a convergence process of East and West German sex-role attitudes after reunification. On the other hand, if the coefficients of the interactions show the same signs as the East German dummy coefficients, this would rather indicate an increase in the gap over the years.

Table 6 depicts the remarkable results of this exercise. In none of the six specifications, we find any evidence at all for an emerging convergence process. Indeed, it rather seems that East Germans became comparatively more egalitarian than West Germans after reunification. In particular, looking at the results for the interaction terms of the East dummy and the years 2004 and 2008, we find five out of six coefficients significant with the signs being identical to the ones of the East Germany dummies. This suggests the existence of a divergence rather than convergence process. Nineteen years after reunification, East and West Germans differ more from each in terms of gender views than they used to in 1991 and 1992, i.e., right after reunification. At the same time as being highly significant, the magnitude of the divergence seems rather substantial. In specification (IV), which deals with the agreement to the statement that it is better for a woman to support her husband's career than to make her own career, the gap between East and 
West Germans has virtually more than doubled 15 years after the fall of the Berlin Wall and even grew further until 2008. But also in specifications (II), (III), (V), and (VI), we see a substantial divergence resulting in a maximum of the gap in 2004 that is roughly 1.3 to 1.5 the size of the gap right after Reunification. From 2004 to 2008, this gap only reduced marginally. Further investigating these dynamics, we find that both East and West Germans adopt more egalitarian sex-role attitudes in the course of the 19 years following German Reunification. However, East Germans start out more egalitarian and follow steeper trend lines towards even less traditional gender views, which ultimately leads to an increase in the East-West gap. The general picture for the other covariates remains unaffected.

\subsection{What Drives the Increase in the Gap?}

Given that East and West Germans have been living in one country since 1990, the persistent and mostly dramatically increasing gap in beliefs about appropriate gender roles seems puzzling - even more so given that other studies have found at least some convergence in terms of preferences for redistribution (Alesina and Fuchs-Schündeln, 2007) and trust (Rainer and Siedler, 2009). Therefore, further investigating this widening of the gap in family values seems a worthwhile exercise. Are there any persistent, or rather increasing, differences in institutions and social policies which might be responsible for the widening of the gap? In the rest of this paper, we first deal with two natural candidates, i.e., differences in child care systems and differences in labor markets. Our analysis, however, shows that the increase in the gap is unlikely to be driven by these factors. This is why, finally, we try to convey the view that social identity may play an important role in explaining the observed widening of the gap in gender role attitudes.

Childcare. The socialist regime in East Germany built up an elaborated child care system while there were hardly any day nurseries - in particular for very young childrenin West Germany. This might well have been one channel through which the socialist regime had an effect on the gender role attitudes of its citizens. Note that many of the child care centers survived reunification and are still in place in today's East Germany. However, after reunification, if anything, we see a slow convergence in the availability of day care nursery places in East and West Germany. This is illustrated in Figure 1. The figure presents data from the German Federal Statistical Office showing that the number of day nursery spaces for children up to 3 years of age per 1,000 children of that age slightly increased in West Germany, while it stayed on a constant level (or rather decreased) in 
East Germany. This renders child care a rather questionable candidate for explaining the widening of the gap in sex-role attitudes between West and East Germans.

Labor markets. The labor market situation in the postunification era substantially differed between East and West Germany, with much higher unemployment rates in the East. Theoretically, the effect of high regional unemployment on gender role attitudes is ambiguous. On the one hand, high regional unemployment rates might discourage women from joining the labor force and rather render them housewives, which could in turn lead to more traditional family values. On the other hand, if high regional unemployment endangers the job of the husband, a wife might just as well join the labor force and search for a job herself in order to minimize the negative effects for the family arising from her husband getting unemployed. The latter hypothesis makes it conceivable that high unemployment in East Germany may have lead to relatively more egalitarian gender role attitudes. As can be seen from Figure 2, unemployment statistics indeed show that, at least in absolute terms, the unemployment rates in East and West Germany diverged rather than converged from 1991 to 2004, which is exactly the time span where we see the greatest divergence in sex-role attitudes.

Yet, it is important to note that causality might also run from sex-role attitudes to unemployment. If people hold the view that a working mother is not harmful to children or the family, women might look for jobs on the labor market, which in turn increases the labor force and ceteris paribus the unemployment rate. This makes it difficult to analyze the causal effect of unemployment on family values. However, if unemployment played a crucial role in explaining the increasing attitude gap, it seems reasonable to assume that further divergence from West German family values should be greatest among those East Germans who are also more likely to be affected by unemployment, i.e., among people in the working age. Therefore, we now split our sample again by cohorts. In the year 2004, where we on average see the greatest divergence in the family values gap, those who were born before 1935 have already reached the retirement age. In contrast, the latest cohort, which includes those individuals born after 1965, is in the working age throughout the whole period of observation. We run probit models analyzing the dynamics of the gap for our earliest and latest cohort separately.

The findings of this exercise are displayed in Table 7. The cohort in the working age, which should be affected by the labor market situation, does not show any indications of divergence at all, which can be seen from the second panel of Table 7. Instead, we observe a slight convergence - at least for the first of the six outcome variables in 2008. In stark 
contrast, the first panel of Table 7 illustrates that the oldest generation shows the biggest differences not only right after Reunification, but that this gap also increases dramatically in the course of the postunification years. This pattern suggests that unemployment should at least not be the main factor explaining the increasing gap in family values between East and West Germans after Reunification.

As a final check of whether differences in unemployment and childcare systems can explain the increasing gap in gender role attitudes between East and West Germans, we include unemployment rates and childcare spaces at a federal state level in our regressions. ${ }^{6}$ Due to endogeneity concerns, we do not over-interpret these results. However, if the general picture is confirmed even in this specification, this might further strengthen our point. From Table 8 we can see that the size of the East dummies decreases, yet they remain highly significant across all our outcome variables. The size and significance of the coefficients on the interactions of the East dummies with the year dummies confirms our previous results. Even when controlling for unemployment rates and childcare spaces, the increasing gap in gender role attitudes between East and West Germans after Reunification remains unexplained.

Social Identity. Given these pieces of evidence, it seems not unreasonable to try the concept of social identity (Akerlof and Kranton, 2000, 2005) as an alternative explanation for the increase of the sex-role attitude gap. Consider Figure 3, which illustrates answers of East German ALLBUS respondents to the question "Do you have feelings of belonging to the former German Democratic Republic (GDR) and its citizens". ${ }^{7}$ The figure clearly demonstrates that more people felt very strongly or quite strongly attached to the former GDR in 2000 and 2008 than right after reunification. Simple regressions reveal that this result is driven in particular by people from earlier cohorts whereas the youngest cohort seems to have weaker emotional ties to the former GDR in 2008 than in 1991. Also note that the variable measuring these emotional ties is highly correlated with our gender role attitudes variables. ${ }^{8}$ One possible line of reasoning is now as follows. After the collapse of the former GDR, the West German politico-economic system was superimposed upon East Germany, and both East and West Germans were promised a bright future

\footnotetext{
${ }^{6}$ Data on childcare spaces for up to three year old children per 1,000 children of that age are available from the German Federal Statistical Office for the years 1994, 1998, and 2002. In order to get proxies for the ratio in 1996, we take the average of the 1994 and 1998 values on a federal state level. Similarly, we compute the respective ratios for 2000 by taking the means of 1998 and 2002. Moreover, we proxy the figures for 1992 (2004) by expanding linear trend lines on the basis of the data from 1994 and 1996 (2000 and 2002).

${ }^{7}$ The question was only asked in the 1991, 2000, and 2008 surveys.

${ }^{8}$ The results from these additional regressions are available from the authors upon request.
} 
in a unified country. Soon, however, reality proved that the process of growing together would be more demanding than sometimes expected. East Germany was confronted with unemployment, which was virtually absent during the socialist regime, and even more, unemployment rates in East Germany reached double the level of West Germany. Disillusioned by reality, East Germans began to identify themselves as a social group. Although the communist regime was unmasked as a regime of suppression and injustice, there were a few aspects that were considered to be worthwhile achievements. One of them was the elaborated childcare system and another the role of women in society. ${ }^{9}$ It is striking to find convergence in redistributional preferences and other attitudes between East and West Germans, yet an impressive divergence for exactly those beliefs that are associated with the arguably positive aspects of the former socialist regime. The divergence in sex-role attitudes we observe might therefore reflect an identity-conserving behavior, one through which East Germans hold up the values central to their past, in particular those related to areas where the positive achievements of the socialist regime are generally accepted. As a final caveat we should note that using our repeated cross-sectional data, we cannot completely rule out that, at least to some degree, these results might also be driven by a selection process, where East Germans not attached to the former GDR are more likely to have moved to West Germany. ${ }^{10}$

\section{Conclusion}

There is evidence showing that attitudes and beliefs concerning appropriate roles for men and women in the family and the workplace influence economic outcomes. However, little is known about the formation and evolution of such beliefs. In particular, it is not clear to what degree politics affects sex-role attitudes.

Drawing upon German separation and reunification as a natural experiment, we show that the socialist regime in the former GDR had a causal impact on sex-role attitudes. After more than four decades of separation, East Germans exhibit far more egalitarian or nontraditional gender role attitudes than their western counterparts. Strikingly, despite a scenario of partial policy convergence, we find that the gap in sex-role attitudes between East and West Germans dramatically increased in the years after reunification. Thus, we identify a remarkable divergence process underneath political unification of Germany. We

\footnotetext{
${ }^{9}$ In West Germany, there have been lively discussions for years about increasing childcare resources and thus allowing women to combine both having a family and a career. However, the childcare system in today's West Germany is still far from being elaborated.

${ }^{10}$ Unfortunately, the German Socioeconomic Panel (GSOEP) does not cover the sex role attitude variables we are interested in.
} 
suggest that this pattern might be explained with a notion of social identity.

Our findings have important implications for a wide range of politico-economic issues. Political regimes can shape values and attitudes and have long-term effects on these attitudes even if a regime itself is no longer in place. Consequently, establishing a common political ground in historically divided regions is not a panacea for creating a convergence of attitudes. What does this mean for one-fits-all politics? For example, when it comes to voting on EU legislation, do member states hold up their very special and typical values and opt against centralized interference in some specific fields? Which issues are more sensitive to these problems of finding consensus? Our results make it conceivable that attitudes are historically shaped and not easily manipulated even in the presence of a general political convergence process.

\section{References}

Akerlof, G. A. and Kranton, R. E. (2000). Economics and identity. The Quarterly Journal of Economics, 115 (3), 715-753.

- and - (2005). Identity and the economics of organizations. The Journal of Economic Perspectives, 19 (1), 9-32.

Alesina, A. and Fuchs-Schündeln, N. (2007). Good-bye lenin (or not?): The effect of communism on people's preferences. American Economic Review, 97 (4), 1507-1528.

Bauernschuster, S., Falck, O., Gold, R. and Stephan, H. (2009). The shadows of the past: Implicit institutions and entrepreneurship. Unpublished manuscript.

Engelhardt, H., Trappe, H. and Dronkers, J. (2002). Differences in family policy and the intergenerational transmission of divorce: A comparison between the former east and west germany. Demographic Research, 6 (1), 295-324.

Fernandez, R. and Fogli, A. (2009). Culture: An empirical investigation of beliefs, work, and fertility. American Economic Journal: Macroeconomics, 1 (1), 146-177.

- , - and Olivetti, C. (2004). Mothers and sons: Preference formation and female force dynamics. Quarterly Journal of Economics, 119 (4), 1249-1299.

Fortin, N. M. (2005). Gender role attitudes and the labour-market outcomes of women across oecd countries. Oxford Review of Economic Policy, 21 (3), 416-438. 
Huinink, J. and SolgA, H. (2007). Occupational opportunities in the gdr: A privilege of the older generations. Zeitschrift für Soziologie, 23 (3), 237-253.

RAiner, H. and Siedler, T. (2009). Does democracy foster trust? Journal of Comparative Economics, 37 (2), 251-269.

Rosenfeld, R. A., Trappe, H. and Gornick, J. C. (2004). Gender and work in germany: Before and after reunification. Annual Review of Sociology, 30, 103-124.

SCHÄFGEN, K. (1998). Die verdoppelung der ungleichheit. sozialstruktur und geschlechterverhältnisse in der bundesrepublik und in der ddr. PhD diss. HumboldtUniversität.

Thornton, A., Alwin, D. F. and Camburn, D. (1983). Causes and consequences of sex-role attitudes and attitude change. American Sociological Review, 48 (2), 211-227.

TRAPPE, H. (1996). Work and family in women's lives in the german democratic republic. Work and Occupations, 23 (4), 354-377. 


\section{Tables and Figures}

Table 1: Determinants of Attitudes toward Working Mothers and Family Models

\begin{tabular}{|c|c|c|c|c|c|c|}
\hline & \multicolumn{3}{|c|}{ Mothers and work } & \multicolumn{3}{|c|}{ Women in the family } \\
\hline & $(\mathrm{l})$ & (II) & (III) & (IV) & $(\mathrm{V})$ & $(\mathrm{VI})$ \\
\hline \multirow[t]{2}{*}{ East } & $.153 * \star \star$ & $.308 * \star \star$ & $.287 * \star \star$ & $.096 * \star \star$ & $.241 * \star \star$ & .146 *** \\
\hline & .005 & .007 & .008 & .007 & .007 & .008 \\
\hline \multirow[t]{2}{*}{ Female } & $.054 * \star \star$ & 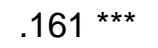 & $.092 * \star \star$ & $.023 * \star \star$ & $.080 * \star \star$ & $.073 * \star \star$ \\
\hline & .005 & .007 & .007 & .007 & .007 & .007 \\
\hline \multirow[t]{2}{*}{ Age } & $.004 * * \star$ & $.009 * \star \star$ & -.000 & -.000 & $.003 * \star \star$ & $.005 * \star *$ \\
\hline & .001 & .001 & .001 & .001 & .001 & .001 \\
\hline \multirow[t]{2}{*}{ Age squared $\left({ }^{\star} 10^{2}\right)$} & $-.004 * \star *$ & $-.011 * \star *$ & $-.003 * * *$ & $-.005 * \star \star$ & $-.010 * * \star$ & $-.011 * \star \star$ \\
\hline & .001 & .001 & .001 & .001 & .001 & .001 \\
\hline \multirow[t]{2}{*}{ Lower secundary education } & $.066 * \star \star$ & $.081 * \star \star$ & .039 & $.117 \star \star \star ~$ & $.117 \star \star \star ~$ & $.080 * \star \star$ \\
\hline & .015 & .025 & .026 & .021 & .024 & .024 \\
\hline \multirow[t]{2}{*}{ Medium secundary education } & $.091 * * *$ & $.129 * \star \star$ & $.107 * \star \star$ & $.199 * \star \star$ & $.225 * * *$ & $.180 * \star *$ \\
\hline & .013 & .025 & .026 & .018 & .022 & .023 \\
\hline \multirow[t]{2}{*}{ Higher secundary education } & .118 *** & $.207 * \star \star$ & $.177 \star \star \star ~$ & $.273 * \star *$ & $.340 * * *$ & $.315 * \star \star$ \\
\hline & .011 & .024 & .027 & .014 & .018 & .019 \\
\hline \multirow[t]{2}{*}{ Other } & $.071 * \star \star$ & $.116 * \star$ & .106 ** & $.151 * \star \star$ & $.225 * \star \star$ & $.218 * \star \star$ \\
\hline & .023 & .049 & .054 & .029 & .033 & .034 \\
\hline \multirow[t]{2}{*}{ Pupil } & $.099 * \star \star$ & $.134 * \star \star$ & .056 & $.189 * * \star$ & $.277 * \star \star$ & $.210 * \star \star$ \\
\hline & .016 & .046 & .050 & .024 & .027 & .035 \\
\hline \multirow[t]{2}{*}{ Year 1992} & .018 ** & .012 & $.036 * \star \star$ & $-.052 * \star *$ & -.026 ** & $.032 * \star \star$ \\
\hline & .008 & .013 & .013 & .012 & .013 & .013 \\
\hline \multirow[t]{2}{*}{ Year 1996} & .032 *** & $.049 * \star \star$ & $.050 * \star *$ & $.013 * \star \star$ & $.033 * * *$ & $.091 * \star \star$ \\
\hline & .008 & .013 & .013 & .012 & .013 & .012 \\
\hline \multirow[t]{2}{*}{ Year 2000} & .050 *** & .113 *** & $.115 * \star \star$ & .022 *** & .030 ** & .163 *** \\
\hline & .008 & .013 & .013 & .011 & .013 & .011 \\
\hline \multirow[t]{2}{*}{ Year 2004} & $.033 * * *$ & $.175 * \star *$ & $.223 * \star \star$ & .121 *** & 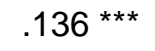 & .176 *** \\
\hline & .008 & .013 & .014 & .010 & .012 & .011 \\
\hline \multirow[t]{2}{*}{ Year 2008} & .068 *** & $.232 * \star \star$ & $.283 * \star \star$ & .118 *** & .151 *** & $.191 * \star \star$ \\
\hline & .008 & .012 & .013 & .010 & .012 & .011 \\
\hline $\mathrm{N}$ & 19,950 & 19,278 & 19,804 & 19,340 & 19,774 & 19,463 \\
\hline Log likelihood & $-8,562$ & $-11,922$ & $-11,934$ & $-10,585$ & $-11,513$ & $-11,670$ \\
\hline \multicolumn{7}{|c|}{$\begin{array}{l}\text { Notes: The table reports probit marginal effects where the columns I) to VI) correspond to the six dummy } \\
\text { outcome variables discussed in the text. Positive coefficients on the explaining variables are associated with } \\
\text { more egalitarian or non-traditional views about gender roles. Omitted categories are West Germany, male, no } \\
\text { secondary education, and year } 1991 \text {. Robust standard errors are given in italics. }{ }^{* * *} 1 \% \text { level of significance, } * * \\
5 \% \text { level of significance, } * 10 \% \text { level of significance. }\end{array}$} \\
\hline
\end{tabular}


Table 2: The East-West Gaps by Gender

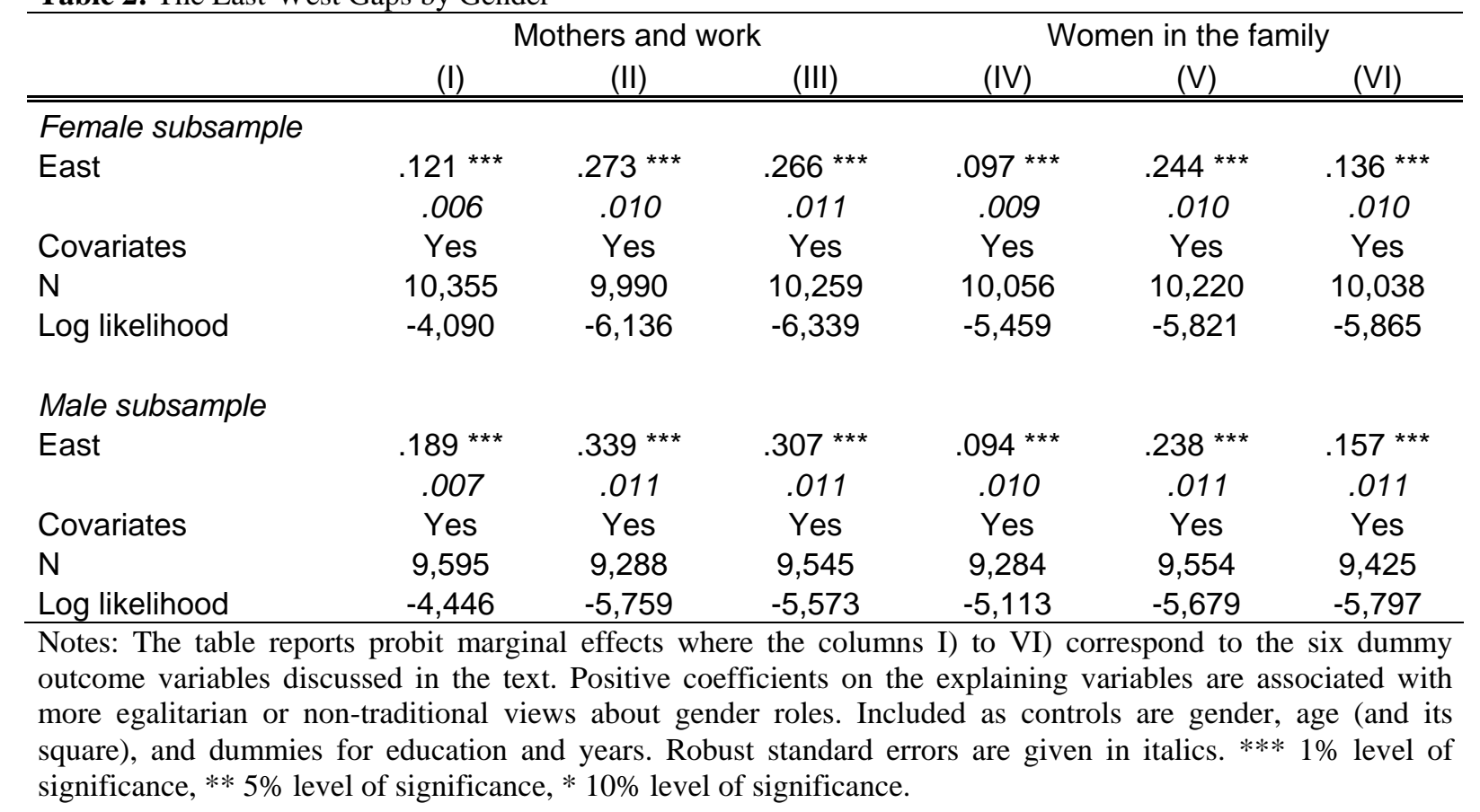


Table 3: Determinants of Attitudes toward Women and Family Models - Federal States Specification

\begin{tabular}{|c|c|c|c|c|c|c|}
\hline & \multicolumn{3}{|c|}{ Mothers and work } & \multicolumn{3}{|c|}{ Women in the family } \\
\hline & $(\mathrm{I})$ & (II) & (III) & (IV) & $(\mathrm{V})$ & $(\mathrm{VI})$ \\
\hline \multirow[t]{2}{*}{ East Berlin } & $.115 * \star \star$ & $.290 * \star \star$ & $.292 * * *$ & $.161 * \star *$ & $.298 * \star \star$ & $.220 * * *$ \\
\hline & .009 & .018 & .022 & .016 & .014 & .018 \\
\hline \multirow[t]{2}{*}{ Brandenburg } & $.130 * \star \star$ & $.307 * \star \star$ & $.296 * \star \star$ & $.106 * * *$ & $.212 * \star *$ & $.162 * \star *$ \\
\hline & .006 & .012 & .015 & .012 & .012 & .013 \\
\hline \multirow[t]{2}{*}{ Mecklenburg W.Pomerania } & $.120 * \star \star$ & $.326 * * *$ & $.363 * * \star$ & $.118 * \star \star$ & $.245 * \star \star$ & $.168 * \star \star$ \\
\hline & .007 & .013 & .016 & .014 & .014 & .016 \\
\hline \multirow[t]{2}{*}{ Saxony } & $.119 * \star \star$ & $.274 * \star \star$ & $.260 * \star \star$ & $.086 * \star \star$ & $.212 * \star \star$ & $.101 * * \star$ \\
\hline & .005 & .010 & .012 & .010 & .010 & .012 \\
\hline \multirow[t]{2}{*}{ Saxony-Anhalt } & $.118 * \star *$ & $.292 * \star *$ & $.306 * * *$ & $.084 * * *$ & $.239 * \star *$ & $.131 * * *$ \\
\hline & .006 & .012 & .014 & .012 & .011 & .013 \\
\hline \multirow[t]{2}{*}{ Thuringia } & $.117 * * *$ & $.265 * \star \star$ & $.274 * \star *$ & $.042 * * *$ & $.177 * \star *$ & $.139 * * *$ \\
\hline & .006 & .013 & .015 & .014 & .013 & .014 \\
\hline Covariates & Yes & Yes & Yes & Yes & Yes & Yes \\
\hline $\mathrm{N}$ & 19,950 & 19,278 & 19,804 & 19,340 & 19,774 & 19,463 \\
\hline Log likelihood & $-8,559$ & $-11,912$ & $-11,918$ & $-10,565$ & $-11,488$ & $-11,650$ \\
\hline
\end{tabular}

Notes: The table reports probit marginal effects where the columns I) to VI) correspond to the six dummy outcome variables discussed in the text. Positive coefficients on the explaining variables are associated with more egalitarian or non-traditional views about gender roles. Included as controls are gender, age (and its square), and dummies for education and years. Robust standard errors are given in italics. *** $1 \%$ level of significance, $* * 5 \%$ level of significance, $* 10 \%$ level of significance. 
Table 4: Attitudes toward Women and Family Models of East German Movers

\begin{tabular}{|c|c|c|c|c|c|c|}
\hline & \multicolumn{3}{|c|}{ Mothers and work } & \multicolumn{3}{|c|}{ Women in the family } \\
\hline & (I) & (II) & (III) & (IV) & $(\mathrm{V})$ & $(\mathrm{VI})$ \\
\hline \multirow[t]{2}{*}{ East-West mover dummy } & $.105 * \star \star$ & $.223 * \star \star$ & $.258 * \star \star$ & .051 & $.129 * \star \star$ & $.140 * \star *$ \\
\hline & .029 & .044 & .046 & .042 & .046 & .043 \\
\hline \multirow[t]{2}{*}{ Female } & $.088 * \star \star$ & $.179 * \star \star$ & $.109 * \star \star$ & .013 & $.057 * \star \star$ & $.073 * \star \star$ \\
\hline & .011 & .013 & .012 & .012 & .013 & .013 \\
\hline \multirow[t]{2}{*}{ Age } & $.007 * * *$ & $.015 * \star \star$ & .004 * & .000 & $.005 * \star$ & $.010 * * *$ \\
\hline & .002 & .002 & .002 & .002 & .002 & .002 \\
\hline \multirow[t]{2}{*}{ Age squared $\left({ }^{\star} 10^{2}\right)$} & $-.008 * * *$ & $-.019 * * *$ & $-.009 * * *$ & $.023 * * *$ & $-.015 * * *$ & $-.018 * * *$ \\
\hline & .002 & .002 & .002 & .002 & .002 & .002 \\
\hline \multirow[t]{2}{*}{ Lower secundary education } & $.093 * \star$ & .127 * & -.081 & .010 & .086 & $.111 *$ \\
\hline & .042 & .067 & .052 & .053 & .065 & .061 \\
\hline \multirow[t]{2}{*}{ Medium secundary education } & $.133 * \star *$ & $.215 * \star \star$ & -.013 & .108 ** & $.223 * \star \star$ & $.221 * \star *$ \\
\hline & .035 & .068 & .053 & .048 & .060 & .055 \\
\hline \multirow[t]{2}{*}{ Higher secundary education } & $.182 * * *$ & $.293 * * *$ & .071 & $.216 * * *$ & $.349 * * *$ & $.361 * * *$ \\
\hline & .031 & .066 & .056 & .040 & .052 & .046 \\
\hline \multirow[t]{2}{*}{ Other } & $.140 * \star *$ & $.217 *$ & .084 & .079 & $.189 *$ & $.284 * \star *$ \\
\hline & .047 & .119 & .117 & .086 & .098 & .071 \\
\hline \multirow[t]{2}{*}{ Pupil } & $.160 * * *$ & $.264 * * *$ & -.023 & .079 & $.206 * * *$ & $.275 * * *$ \\
\hline & .030 & .089 & .076 & .072 & .078 & .059 \\
\hline \multirow[t]{2}{*}{ Year 1992} & .010 & -.001 & .007 & $-.069 * * *$ & $-.055 * * *$ & .012 \\
\hline & .015 & .019 & .018 & .018 & .019 & .019 \\
\hline \multirow[t]{2}{*}{ Year 2000} & $.066 * \star *$ & $.098 * \star \star$ & $.055 * \star \star$ & .033 * & .025 & $.152 * \star *$ \\
\hline & .014 & .019 & .018 & .017 & .020 & .018 \\
\hline \multirow[t]{2}{*}{ Year 2004} & $.043 * * *$ & $.128 * \star \star$ & $.149 * \star \star$ & $.126 * \star \star$ & $.130 * * *$ & $.171 * \star \star$ \\
\hline & .015 & .020 & .020 & .016 & .020 & .019 \\
\hline $\mathrm{N}$ & 6,453 & 6,237 & 6,433 & 6,282 & 6,417 & 6,318 \\
\hline Log likelihood & $-3,326$ & $-3,931$ & $-3,647$ & $-3,335$ & $-3,801$ & $-3,778$ \\
\hline \multicolumn{7}{|c|}{$\begin{array}{l}\text { Notes: The table reports probit marginal effects where the columns I) to VI) correspond to the six dummy } \\
\text { outcome variables discussed in the text. Positive coefficients on the explaining variables are associated with } \\
\text { more egalitarian or non-traditional views about gender roles. Omitted categories are born and living in Wes } \\
\text { Germany, male, no secondary education, and year } 1991 \text {. Robust standard errors are given in italics. } * * * 1 \% \text { leve } \\
\text { of significance, } * * 5 \% \text { level of significance, } * 10 \% \text { level of significance. }\end{array}$} \\
\hline
\end{tabular}


Table 5: The East-West Gaps by Cohort

\begin{tabular}{|c|c|c|c|c|c|c|}
\hline & \multicolumn{3}{|c|}{ Mothers and work } & \multicolumn{3}{|c|}{ Women in the family } \\
\hline & $(\mathrm{I})$ & (II) & (III) & (IV) & $(\mathrm{V})$ & $(\mathrm{VI})$ \\
\hline \multicolumn{7}{|l|}{ Cohort -1935 } \\
\hline \multirow[t]{2}{*}{ East } & $.210 * \star \star$ & 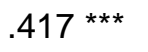 & $.340 * \star \star$ & $.192 * \star \star$ & $.365^{\star \star \star}$ & $.235^{\star \star \star}$ \\
\hline & .012 & .015 & .015 & .016 & .015 & .016 \\
\hline Covariates & Yes & Yes & Yes & Yes & Yes & Yes \\
\hline $\mathrm{N}$ & 4,247 & 4,064 & 4,220 & 4,043 & 4,219 & 4,099 \\
\hline Log likelihood & $-2,092$ & $-2,335$ & $-2,170$ & $-2,656$ & $-2,410$ & $-2,495$ \\
\hline \multicolumn{7}{|c|}{ Cohort 1935-1945 } \\
\hline \multirow{2}{*}{ East } & $.170^{* \star \star}$ & $.320 * \star \star$ & $.324 * \star \star$ & $.159 * \star \star$ & $.315 * * *$ & $.177^{\star \star \star}$ \\
\hline & .012 & .017 & .017 & .016 & .017 & .018 \\
\hline Covariates & Yes & Yes & Yes & Yes & Yes & Yes \\
\hline $\mathrm{N}$ & 3,477 & 3,372 & 3,445 & 3,360 & 3,432 & 3,389 \\
\hline Log likelihood & $-1,489$ & $-2,086$ & $-1,956$ & $-2,044$ & $-2,095$ & $-2,178$ \\
\hline \multicolumn{7}{|c|}{ Cohort 1945-1955 } \\
\hline \multirow[t]{2}{*}{ East } & $.128^{* \star \star}$ & $.259 * \star \star$ & $.263^{* \star \star}$ & $.035 * *$ & $.168 * \star \star$ & $.098^{* \star *}$ \\
\hline & .012 & .018 & .019 & .017 & .018 & .018 \\
\hline Covariates & Yes & Yes & Yes & Yes & Yes & Yes \\
\hline $\mathrm{N}$ & 3,480 & 3,374 & 3,463 & 3,379 & 3,448 & 3,415 \\
\hline Log likelihood & $-1,371$ & $-2,123$ & $-2,134$ & $-1,828$ & $-2,064$ & $-2,082$ \\
\hline \multicolumn{7}{|c|}{ Cohort 1955-1965 } \\
\hline \multirow[t]{2}{*}{ East } & $.138 * \star \star$ & $.249 * \star \star$ & $.235^{\star \star \star}$ & .016 & $.144 * \star *$ & $.091 * * \star$ \\
\hline & .011 & .017 & .017 & .014 & .015 & .016 \\
\hline Covariates & Yes & Yes & Yes & Yes & Yes & Yes \\
\hline $\mathrm{N}$ & 4,327 & 4,205 & 4,300 & 4,226 & 4,290 & 4,240 \\
\hline Log likelihood & $-1,732$ & $-2,631$ & $-2,782$ & $-2,037$ & $-2,424$ & $-2,409$ \\
\hline \multicolumn{7}{|l|}{ Cohort 1965- } \\
\hline \multirow[t]{2}{*}{ East } & $.113 * \star \star$ & 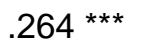 & $.239 * \star \star$ & .031 ** & $.128 * \star \star$ & $.085 * \star *$ \\
\hline & .011 & .016 & .017 & .013 & .014 & .015 \\
\hline Covariates & Yes & Yes & Yes & Yes & Yes & Yes \\
\hline $\mathrm{N}$ & 4,416 & 4,262 & 4,373 & 4,329 & 4,383 & 4,319 \\
\hline Log likelihood & $-1,835$ & $-2,669$ & $-2,805$ & $-1,908$ & $-2,400$ & $-2,421$ \\
\hline
\end{tabular}

Notes: The table reports probit marginal effects where the columns I) to VI) correspond to the six dummy outcome variables discussed in the text. Positive coefficients on the explaining variables are associated with more egalitarian or non-traditional views about gender roles. Included as controls are gender, age (and its square), and dummies for education and years. Robust standard errors are given in italics. ${ }^{* * *} 1 \%$ level of significance, ** $5 \%$ level of significance, * $10 \%$ level of significance. 
Table 6: Dynamics of Attitudes toward Working Mothers and Family Models

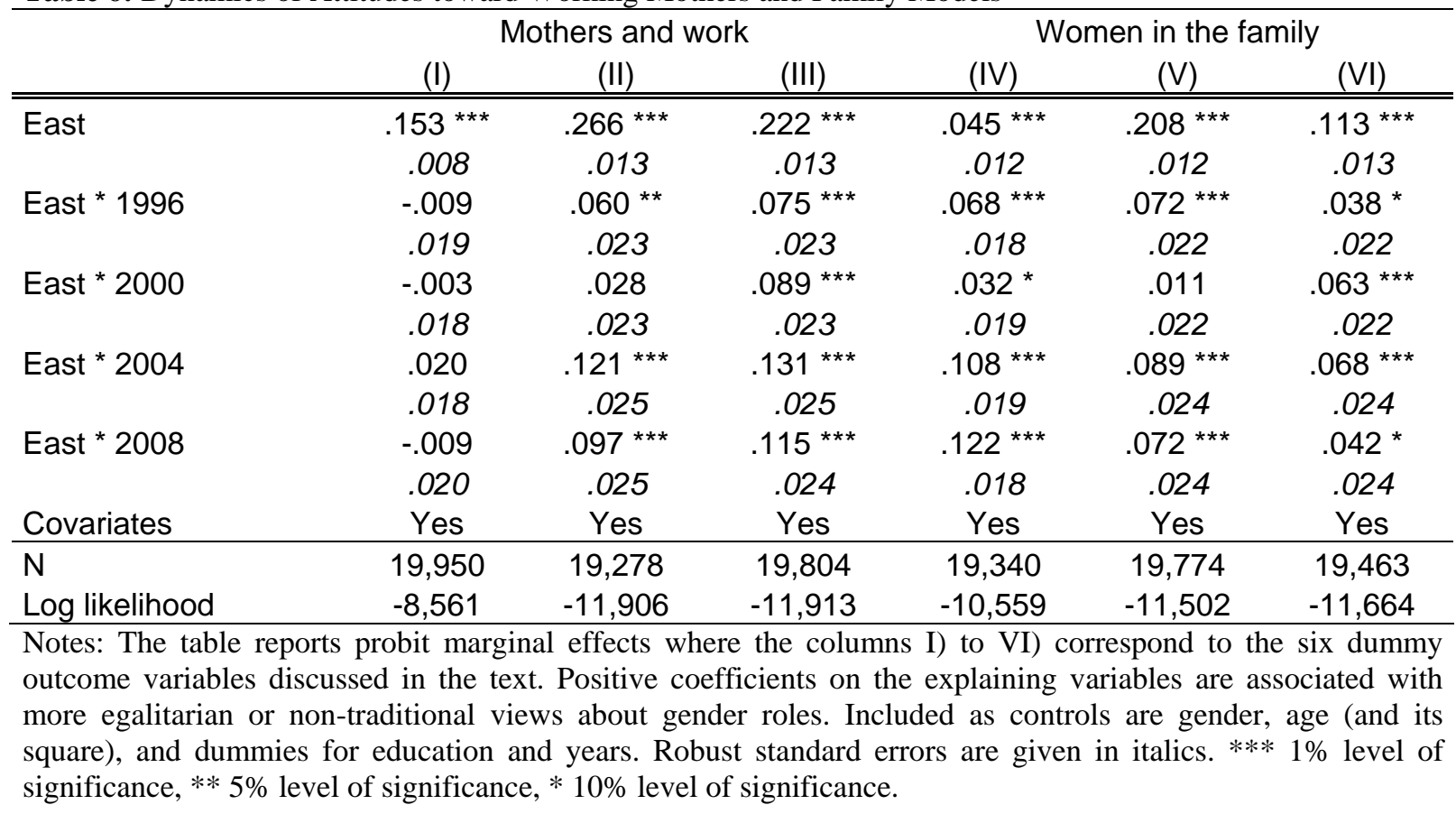


Figure 1: Childcare spaces in East and West Germany

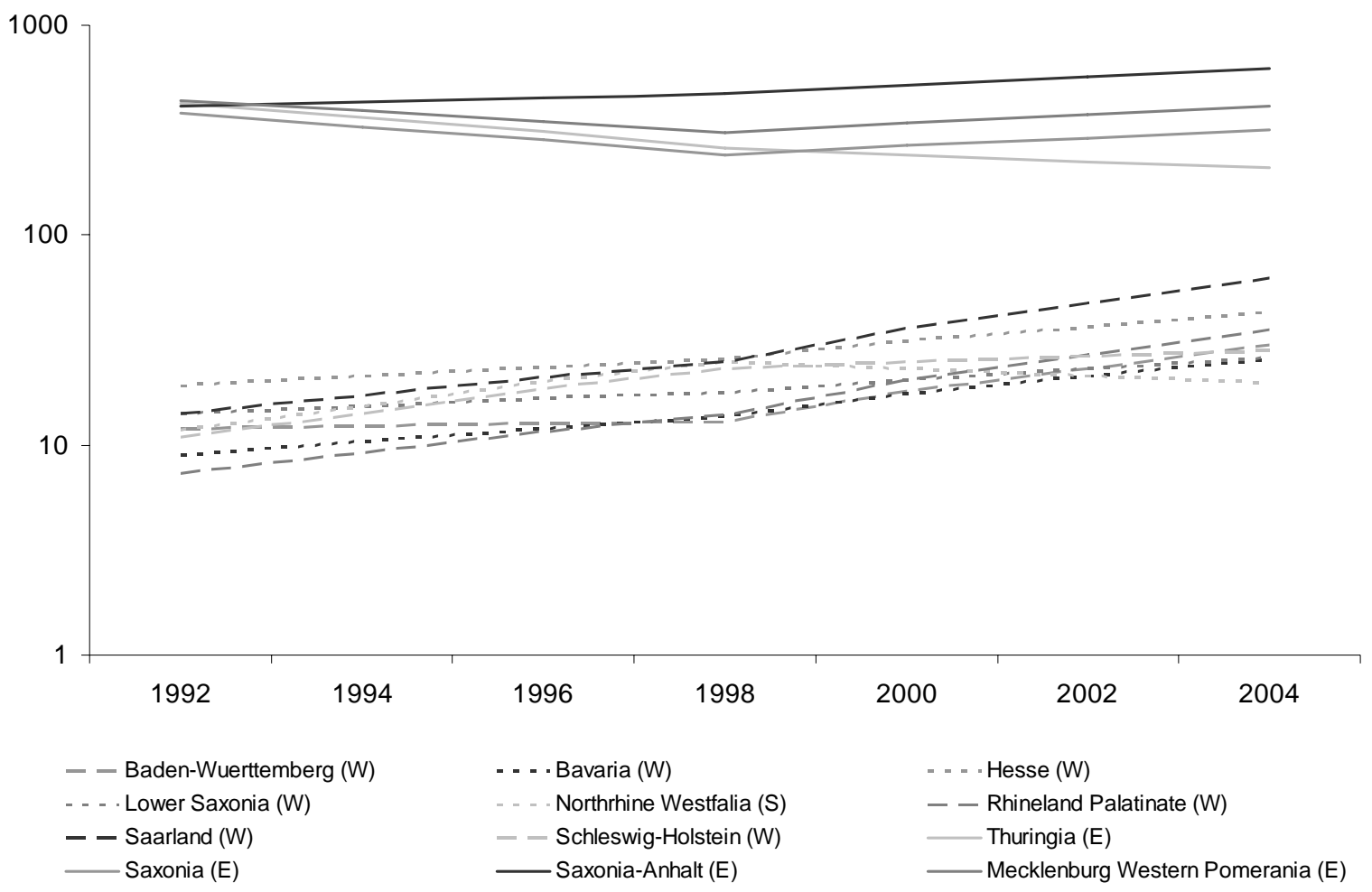

Notes: The figure shows the development of childcare spaces for up to 3 year old children per 1,000 children of that age on a federal state level. East German federal states are represented by solid lines, whereas West German federal states are represented by dotted lines; the y-axis is log-scaled. Data source: German Federal Statistical Office (years 1994, 1998, and 2002) and own calculations (linear trends for the years 1992, 1996, 2000, and 2004). 
Figure 2: Unemployment Rate in East and West Germany

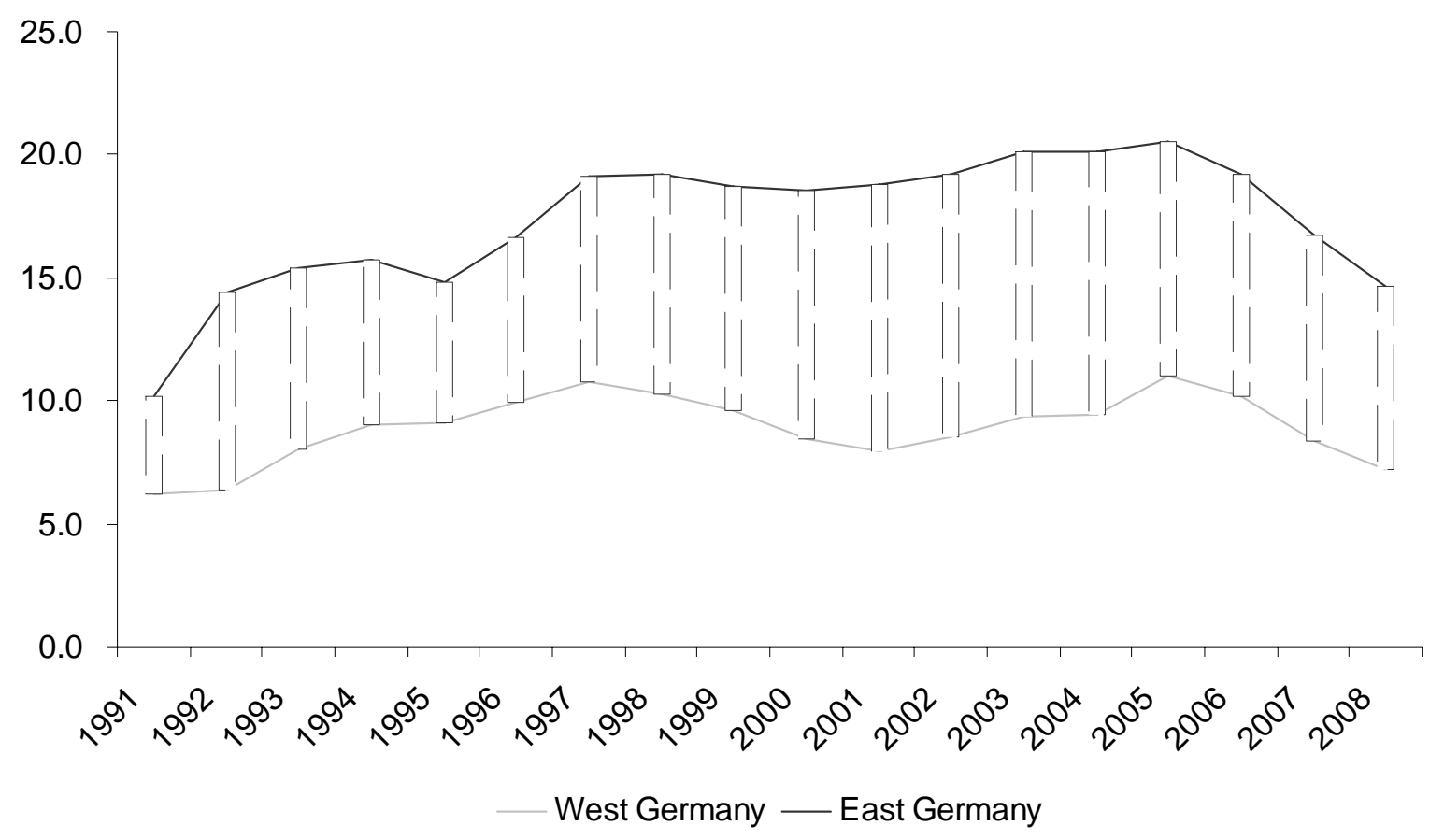

Notes: The figure shows the development of unemployment rates (in percent) in East and West Germany. Data source: Statistics from the German Federal Employment Agency. 
Table 7: Dynamics of the East-West Gap by Cohorts

\begin{tabular}{|c|c|c|c|c|c|c|}
\hline & \multicolumn{3}{|c|}{ Mothers and work } & \multicolumn{3}{|c|}{ Women in the family } \\
\hline & ( $)$ & (II) & (III) & (IV) & $(\mathrm{V})$ & $(\mathrm{VI})$ \\
\hline \multicolumn{7}{|l|}{ Cohort -1935 } \\
\hline \multirow[t]{2}{*}{ East dummy } & $.186 * \star \star$ & $.369 * * *$ & $.249 * * *$ & $.086 * * *$ & $.315 * \star \star$ & $.158 * \star \star$ \\
\hline & .017 & .024 & .023 & .025 & .024 & .025 \\
\hline \multirow[t]{2}{*}{ East * 1996} & $.080 * *$ & $.126 * *$ & .102 ** & $.181 * \star *$ & .116 ** & .106 ** \\
\hline & .033 & .049 & .046 & .044 & .048 & .047 \\
\hline \multirow[t]{2}{*}{ East * 2000} & .018 & .032 & $.129 * \star *$ & .112 ** & .026 & $.130 * \star \star$ \\
\hline & .040 & .048 & .047 & .046 & .045 & .048 \\
\hline \multirow[t]{2}{*}{ East * 2004} & $.088 * \star$ & $.149 * \star$ & $.275 * \star \star$ & $.231 * \star \star$ & .113 * & $.204 * * *$ \\
\hline & .040 & .064 & .063 & .053 & .060 & .060 \\
\hline \multirow[t]{2}{*}{ East * 2008} & .023 & .112 * & $.267 * * *$ & $.316 * * \star$ & $.175 * \star \star$ & $.155 * \star \star$ \\
\hline & .051 & .064 & .063 & .047 & .062 & .060 \\
\hline Covariates & Yes & Yes & Yes & Yes & Yes & Yes \\
\hline $\mathrm{N}$ & 4,247 & 4,064 & 4,220 & 4,043 & 4,219 & 4,099 \\
\hline Log likelihood & $-2,088$ & $-2,329$ & $-2,151$ & $-2,633$ & $-2,403$ & $-2,486$ \\
\hline \multicolumn{7}{|l|}{ Cohort 1965- } \\
\hline \multirow[t]{2}{*}{ East dummy } & .158 *** & $.252 * \star *$ & $.260 * * *$ & .015 & $.140 * \star \star$ & $.089 * * *$ \\
\hline & .023 & .036 & .039 & .029 & .031 & .033 \\
\hline \multirow[t]{2}{*}{ East * 1996} & -.085 & -.014 & -.008 & .006 & -.011 & .039 \\
\hline & .061 & .061 & .061 & .043 & .055 & .063 \\
\hline \multirow[t]{2}{*}{ East * 2000} & -.062 & -.001 & -.052 & -.020 & -.063 & -.058 \\
\hline & .054 & .055 & .054 & .042 & .052 & .048 \\
\hline \multirow[t]{2}{*}{ East * 2004} & -.080 & .052 & .002 & .042 & .032 & .039 \\
\hline & .054 & .056 & .055 & .035 & .048 & .046 \\
\hline \multirow[t]{2}{*}{ East * 2008} & -.112 ** & .018 & -.040 & .045 & -.016 & -.027 \\
\hline & .056 & .055 & .053 & .033 & .049 & .049 \\
\hline Covariates & Yes & Yes & Yes & Yes & Yes & Yes \\
\hline $\mathrm{N}$ & 4,416 & 4,262 & 4,373 & 4,329 & 4,383 & 4,319 \\
\hline Log likelihood & $-1,833$ & $-2,669$ & $-2,804$ & $-1,906$ & $-2,398$ & $-2,419$ \\
\hline
\end{tabular}

Notes: The table reports probit marginal effects where the columns I) to VI) correspond to the six dummy outcome variables discussed in the text. Positive coefficients on the explaining variables are associated with more egalitarian or non-traditional views about gender roles. Included as controls are gender, age (and its square), and dummies for education and years. Robust standard errors are given in italics. ${ }^{* * *} 1 \%$ level of significance, $* * 5 \%$ level of significance, $* 10 \%$ level of significance. 
Table 8: Dynamics of the East-West Gap with Regional Controls

\begin{tabular}{|c|c|c|c|c|c|c|}
\hline & \multicolumn{3}{|c|}{ Mothers and work } & \multicolumn{3}{|c|}{ Women in the family } \\
\hline & 1 & II & III & IV & $\mathrm{V}$ & VI \\
\hline \multirow[t]{2}{*}{ East } & $.121 * \star \star$ & $.170 * \star \star$ & 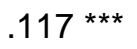 & $.068 * *$ & $.173 * \star \star$ & $.103 * \star \star$ \\
\hline & .020 & .031 & .030 & .028 & .030 & .030 \\
\hline \multirow[t]{2}{*}{ East * 1996} & -.016 & $.071 * * *$ & $.068 * *$ & .050 ** & .056 ** & .021 \\
\hline & .023 & .027 & .027 & .023 & .027 & .026 \\
\hline \multirow[t]{2}{*}{ East * 2000} & -.020 & .026 & $.063 * \star$ & .016 & -.019 & $.045 *$ \\
\hline & .024 & .028 & .027 & .025 & .029 & .027 \\
\hline \multirow[t]{2}{*}{ East * 2004} & .002 & $.116 * * *$ & $.101 * \star \star$ & $.098 * \star \star$ & $.059 *$ & .047 \\
\hline & .024 & .030 & .030 & .024 & .030 & .029 \\
\hline \multirow[t]{2}{*}{ Unemployment rate } & $.004 * \star$ & $.005 * \star$ & $.006 * *$ & -.002 & .004 & .001 \\
\hline & .002 & .003 & .003 & .002 & .003 & .003 \\
\hline \multirow[t]{2}{*}{ Childcare spaces $\left({ }^{\star} 10^{2}\right)$} & .005 & .015 ** & $.019 * \star \star$ & .005 & .009 & .007 \\
\hline & .006 & .007 & .007 & .007 & .007 & .007 \\
\hline Other covariates & Yes & Yes & Yes & Yes & Yes & Yes \\
\hline $\mathrm{N}$ & 13,551 & 13,058 & 13,441 & 13,103 & 13,410 & 13,208 \\
\hline Log likelihood & $-5,918$ & $-8,080$ & $-7,982$ & $-7,264$ & $-7,815$ & $-7,934$ \\
\hline
\end{tabular}

Notes: The table reports probit marginal effects where the columns I) to VI) correspond to the six dummy outcome variables discussed in the text. Positive coefficients on the explaining variables are associated with more egalitarian or non-traditional views about gender roles. Included as controls are gender, age (and its square), dummies for education and years, the unemployment rate at the federal state level, and the number of childcare spaces for up to three years old children per 1,000 children of that age at the federal state level. Robust standard errors are given in italics. *** $1 \%$ level of significance, ** $5 \%$ level of significance, * $10 \%$ level of significance. 
Figure 3: East Germans’ emotional ties to the former GDR

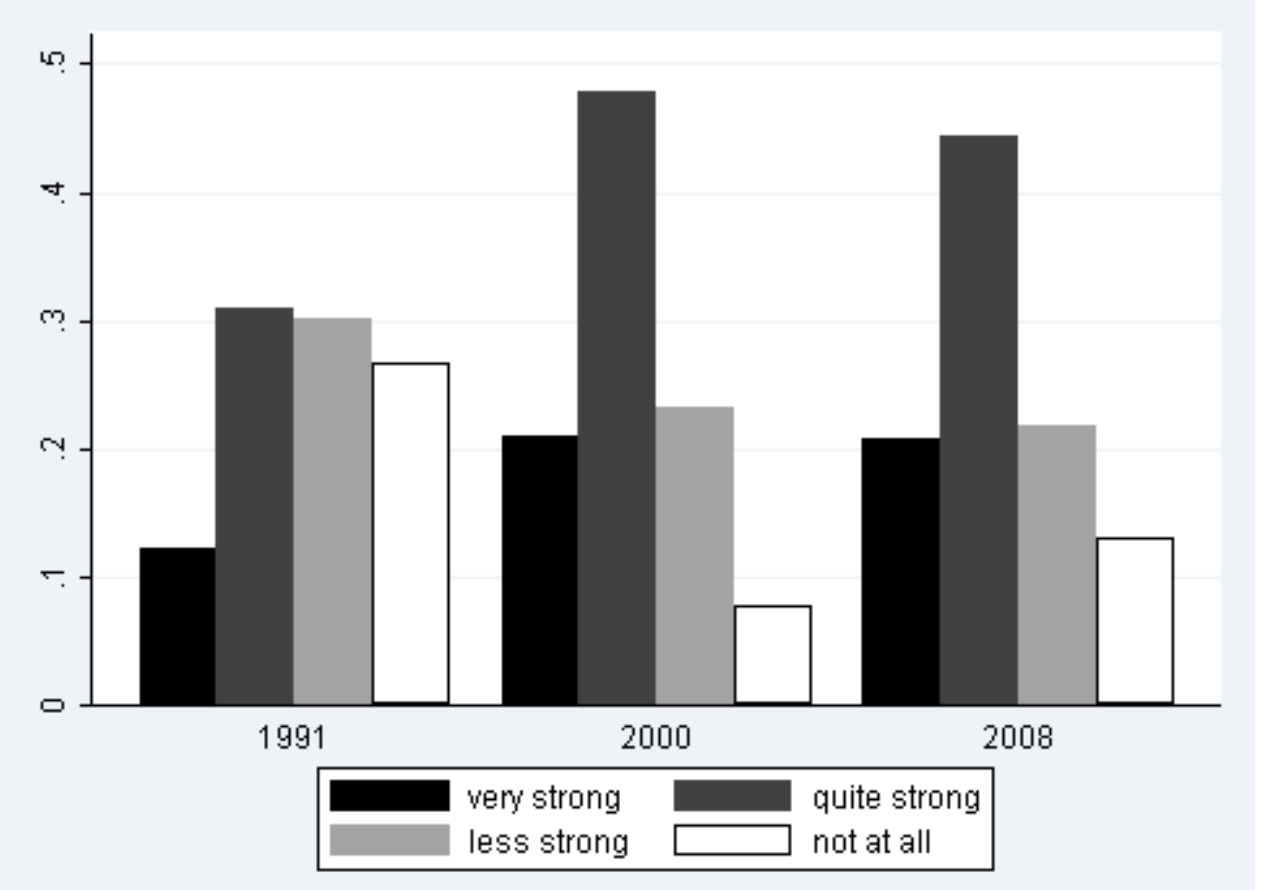

Notes: The graph represents answers of people living in East Germany to the question “Do you have feelings of belonging to the former GDR and its citizens?". Respondents could choose one out of four categories, namely „very strong“, “quite strong”, „less strong“, or “not at all”. 


\section{Appendix}

Appendix 1: Summary statistics

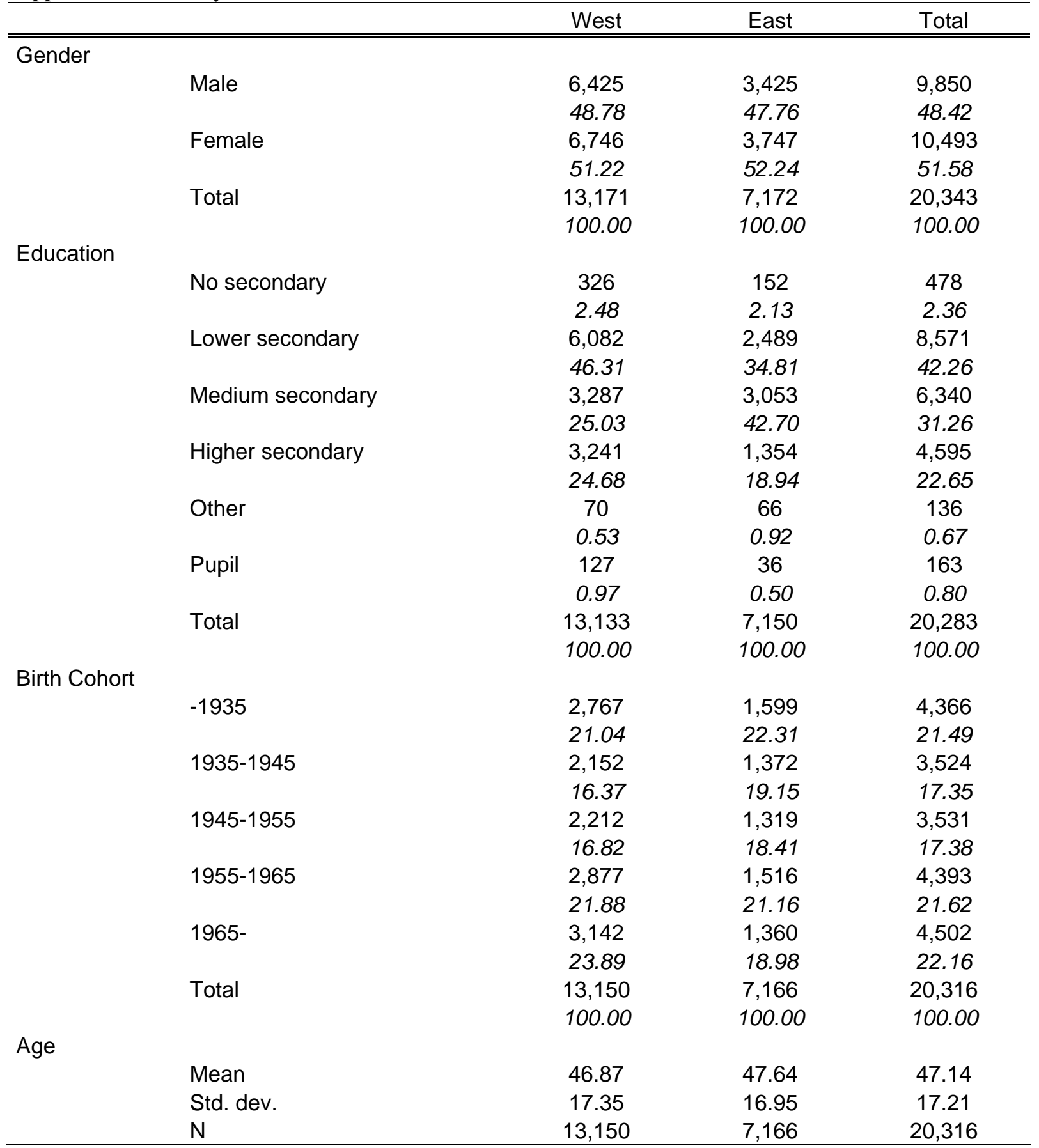

Notes: Unless otherwise specified, the figures show number of observations in each cell; percentage shares are given in italics. 


\section{CESifo Working Paper Series}

for full list see www.cesifo-group.org/wp

(address: Poschingerstr. 5, 81679 Munich, Germany, office@cesifo.de)

2893 Johannes Binswanger and Daniel Schunk, What is an Adequate Standard of Living during Retirement?, December 2009

2894 Armin Falk and James J. Heckman, Lab Experiments are a Major Source of Knowledge in the Social Sciences, December 2009

2895 Hartmut Egger and Daniel Etzel, The Impact of Trade on Employment, Welfare, and Income Distribution in Unionized General Oligopolistic Equilibrium, December 2009

2896 Julian Rauchdobler, Rupert Sausgruber and Jean-Robert Tyran, Voting on Thresholds for Public Goods: Experimental Evidence, December 2009

2897 Michael McBride and Stergios Skaperdas, Conflict, Settlement, and the Shadow of the Future, December 2009

2898 Ben J. Heijdra and Laurie S. M. Reijnders, Economic Growth and Longevity Risk with Adverse Selection, December 2009

2899 Johannes Becker, Taxation of Foreign Profits with Heterogeneous Multinational Firms, December 2009

2900 Douglas Gale and Piero Gottardi, Illiquidity and Under-Valuation of Firms, December 2009

2901 Donatella Gatti, Christophe Rault and Anne-Gaël Vaubourg, Unemployment and Finance: How do Financial and Labour Market Factors Interact?, December 2009

2902 Arno Riedl, Behavioral and Experimental Economics Can Inform Public Policy: Some Thoughts, December 2009

2903 Wilhelm K. Kohler and Marcel Smolka, Global Sourcing Decisions and Firm Productivity: Evidence from Spain, December 2009

2904 Marcel Gérard and Fernando M. M. Ruiz, Corporate Taxation and the Impact of Governance, Political and Economic Factors, December 2009

2905 Mikael Priks, The Effect of Surveillance Cameras on Crime: Evidence from the Stockholm Subway, December 2009

2906 Xavier Vives, Asset Auctions, Information, and Liquidity, January 2010

2907 Edwin van der Werf, Unilateral Climate Policy, Asymmetric Backstop Adoption, and Carbon Leakage in a Two-Region Hotelling Model, January 2010 
2908 Margarita Katsimi and Vassilis Sarantides, Do Elections Affect the Composition of Fiscal Policy?, January 2010

2909 Rolf Golombek, Mads Greaker and Michael Hoel, Climate Policy without Commitment, January 2010

2910 Sascha O. Becker and Ludger Woessmann, The Effect of Protestantism on Education before the Industrialization: Evidence from 1816 Prussia, January 2010

2911 Michael Berlemann, Marco Oestmann and Marcel Thum, Demographic Change and Bank Profitability. Empirical Evidence from German Savings Banks, January 2010

2912 Øystein Foros, Hans Jarle Kind and Greg Shaffer, Mergers and Partial Ownership, January 2010

2913 Sean Holly, M. Hashem Pesaran and Takashi Yamagata, Spatial and Temporal Diffusion of House Prices in the UK, January 2010

2914 Christian Keuschnigg and Evelyn Ribi, Profit Taxation and Finance Constraints, January 2010

2915 Hendrik Vrijburg and Ruud A. de Mooij, Enhanced Cooperation in an Asymmetric Model of Tax Competition, January 2010

2916 Volker Meier and Martin Werding, Ageing and the Welfare State: Securing Sustainability, January 2010

2917 Thushyanthan Baskaran and Zohal Hessami, Globalization, Redistribution, and the Composition of Public Education Expenditures, January 2010

2918 Angel de la Fuente, Testing, not Modelling, the Impact of Cohesion Support: A Theoretical Framework and some Preliminary Results for the Spanish Regions, January 2010

2919 Bruno S. Frey and Paolo Pamini, World Heritage: Where Are We? An Empirical Analysis, January 2010

2920 Susanne Ek and Bertil Holmlund, Family Job Search, Wage Bargaining, and Optimal Unemployment Insurance, January 2010

2921 Mariagiovanna Baccara, Allan Collard-Wexler, Leonardo Felli and Leeat Yariv, Gender and Racial Biases: Evidence from Child Adoption, January 2010

2922 Kurt R. Brekke, Roberto Cellini, Luigi Siciliani and Odd Rune Straume, Competition and Quality in Regulated Markets with Sluggish Demand, January 2010

2923 Stefan Bauernschuster, Oliver Falck and Niels Große, Can Competition Spoil Reciprocity? - A Laboratory Experiment, January 2010 
2924 Jerome L. Stein, A Critique of the Literature on the US Financial Debt Crisis, January 2010

2925 Erkki Koskela and Jan König, Profit Sharing, Wage Formation and Flexible Outsourcing under Labor Market Imperfection, January 2010

2926 Gabriella Legrenzi and Costas Milas, Spend-and-Tax Adjustments and the Sustainability of the Government’s Intertemporal Budget Constraint, January 2010

2927 Piero Gottardi, Jean Marc Tallon and Paolo Ghirardato, Flexible Contracts, January 2010

2928 Gebhard Kirchgässner and Jürgen Wolters, The Role of Monetary Aggregates in the Policy Analysis of the Swiss National Bank, January 2010

2929 J. Trent Alexander, Michael Davern and Betsey Stevenson, Inaccurate Age and Sex Data in the Census PUMS Files: Evidence and Implications, January 2010

2930 Stefan Krasa and Mattias K. Polborn, Competition between Specialized Candidates, January 2010

2931 Yin-Wong Cheung and Xingwang Qian, Capital Flight: China’s Experience, January 2010

2932 Thomas Hemmelgarn and Gaetan Nicodeme, The 2008 Financial Crisis and Taxation Policy, January 2010

2933 Marco Faravelli, Oliver Kirchkamp and Helmut Rainer, Social Welfare versus Inequality Concerns in an Incomplete Contract Experiment, January 2010

2934 Mohamed El Hedi Arouri and Christophe Rault, Oil Prices and Stock Markets: What Drives what in the Gulf Corporation Council Countries?, January 2010

2935 Wolfgang Lechthaler, Christian Merkl and Dennis J. Snower, Monetary Persistence and the Labor Market: A New Perspective, January 2010

2936 Klaus Abberger and Wolfgang Nierhaus, Markov-Switching and the Ifo Business Climate: The Ifo Business Cycle Traffic Lights, January 2010

2937 Mark Armstrong and Steffen Huck, Behavioral Economics as Applied to Firms: A Primer, February 2010

2938 Guglielmo Maria Caporale and Alessandro Girardi, Price Formation on the EuroMTS Platform, February 2010

2939 Hans Gersbach, Democratic Provision of Divisible Public Goods, February 2010

2940 Adam Isen and Betsey Stevenson, Women’s Education and Family Behavior: Trends in Marriage, Divorce and Fertility, February 2010 
2941 Peter Debaere, Holger Görg and Horst Raff, Greasing the Wheels of International Commerce: How Services Facilitate Firms’ International Sourcing, February 2010

2942 Emanuele Forlani, Competition in the Service Sector and the Performances of Manufacturing Firms: Does Liberalization Matter?, February 2010

2943 James M. Malcomson, Do Managers with Limited Liability Take More Risky Decisions? An Information Acquisition Model, February 2010

2944 Florian Englmaier and Steve Leider, Gift Exchange in the Lab - It is not (only) how much you give ..., February 2010

2945 Andrea Bassanini and Giorgio Brunello, Barriers to Entry, Deregulation and Workplace Training: A Theoretical Model with Evidence from Europe, February 2010

2946 Jan-Emmanuel De Neve, James H. Fowler and Bruno S. Frey, Genes, Economics, and Happiness, February 2010

2947 Camille Cornand and Frank Heinemann, Measuring Agents' Reaction to Private and Public Information in Games with Strategic Complementarities, February 2010

2948 Roel Beetsma and Massimo Giuliodori, Discretionary Fiscal Policy: Review and Estimates for the EU, February 2010

2949 Agnieszka Markiewicz, Monetary Policy, Model Uncertainty and Exchange Rate Volatility, February 2010

2950 Hans Dewachter and Leonardo Iania, An Extended Macro-Finance Model with Financial Factors, February 2010

2951 Helmuth Cremer, Philippe De Donder and Pierre Pestieau, Education and Social Mobility, February 2010

2952 Zuzana Brixiová and Balázs Égert, Modeling Institutions, Start-Ups and Productivity during Transition, February 2010

2953 Roland Strausz, The Political Economy of Regulatory Risk, February 2010

2954 Sanjay Jain, Sumon Majumdar and Sharun W. Mukand, Workers without Borders? Culture, Migration and the Political Limits to Globalization, February 2010

2955 Andreas Irmen, Steady-State Growth and the Elasticity of Substitution, February 2010

2956 Bengt-Arne Wickström, The Optimal Babel - An Economic Framework for the Analysis of Dynamic Language Rights, February 2010

2957 Stefan Bauernschuster and Helmut Rainer, From Politics to the Family: How Sex-Role Attitudes Keep on Diverging in Reunified Germany, February 2010 